\title{
DEVELOPMENT OF OPTIMIZED SUBSTITUTION RATIO FOR WHEAT- CASSAVA-AFRICAN YAM BEAN FLOUR COMPOSITE FOR NIGERIAN BREAD INDUSTRIES
}

\author{
I. E. Nwatu ${ }^{1}$, O. C. Nwajinka ${ }^{2, *}$ and A. B. Muochebe ${ }^{3}$ \\ 1, 2, 3, DePARTMENT OF AGRICULTURAL AND BioReSOURCES ENGINEERING, NNAMDi AZIKIWE UNIVERSITY, \\ AWKA, ANAMBRA STATE, NIGERIA \\ E-mail addresses: ${ }^{1}$ nsnwatu@gmail.com, 2 oc.nwajinka@unizik.edu.ng, \\ 3 muochebebonaventure@gmail.com
}

\begin{abstract}
An optimization study of the mix ratio for substitution of Wheat flour with Cassava and African Yam Bean flours (AYB) was carried out and reported in this paper. The aim was to obtain a mix ratio that would optimise selected physical properties of the bread. Wheat flour was substituted with Cassava and African Yam Bean flours at different levels: $80 \%$ to $100 \%$ of wheat, $0 \%$ to $10 \%$ of cassava flour and $0 \%$ to $10 \%$ for $A Y B$ flour. The experiment was conducted in mixture design which was generated and analysed by Design-Expert Software 11 version. The Composite dough was prepared in different mix ratios according to the design matrix and subsequently baked under the same conditions and analysed for the following loaf quality attributes: Loaf Specific Volume, Bread Crumb Hardness and Crumb Colour Index as response variables. The objective functions were to maximize Loaf Specific Volume, minimize Wheat flour, Bread Crumb Hardness and Crumb Colour Index to obtain the most suitable substitution ratio acceptable to consumers. Predictive models for the response variables were developed with the coefficient of determination $\left(R^{2}\right)$ of 0.991 for Loaf Specific Volume (LSV) while that of Bread Crumb Hardness (BCH) and Crumb Colour Index (CCI) were 0.834 and 0.895 respectively at $95 \%$ confidence interval (CI). The predicted optimal substitution ratio was obtained as follows: $88 \%$ Wheat flour, $10 \%$ Cassava flour, and 2\% AYB flour. At this formulation, the predicted Loaf Specific Volume was $2.11 \mathrm{~cm}^{3} / \mathrm{g}$, Bread Crumb Hardness was 25.12N, and Crumb Colour Index was 18.88. The study shows that addition of $2 \%$ of AYB flour in the formulation would help to optimise the LSV, $B C H$ and the CCI of the Wheat-Cassava flour bread at the mix ratio of 88:10. Application of the results of this study in bread industries will reduce the cost of bread in Nigeria, which is influenced by the rising cost of imported wheat. This is a significant development because wheat flour was the sole baking flour in Nigeria before wheat substitution initiative.
\end{abstract}

Keywords: Bread, wheat, Cassava, African Yam Bean, Flour, Dough, Loaf Specific Volume, Crumb Hardness, Crumb Colour Index

\section{INTRODUCTION}

Bread is the most widely consumed food by all social classes around the world. It represents about $80 \%$ of the baked products sub-sector in Nigeria [1]. However, bread is relatively expensive in tropical countries where wheat is imported for bakery industries [2]. This is because wheat is a temperate crop that will not do well under tropical conditions as a result of unfavourable soil and climatic conditions [3]. Whole-wheat grain consists of the entire grain, and, unlike refined grains, they still contain bran and germ, which are rich in dietary fibre and micronutrients [4]. Whole-grain foods are associated with reduced risk of several chronic diet-related diseases and it contains a lot of compounds with reputed health benefits [5].

* Corresponding author, tel: +234 - 803-668- 9930 
The bread industry commands a large market share in Nigeria. According to KPMG [1], the bread industry is worth $\$ 122.1$ billion and about $72 \%$ market share is allocated to the small and medium-sized bakeries. Majority of the bread consumed in Nigeria are baked by small and medium scale bakeries and come in different sizes that suit the consumer's need, whose standard could be compromised by inadequate quality control.

Nigeria, being a tropical country in sub-Saharan Africa, does not have the agronomic variables that support profitable and economical production of wheat. This circumstance causes bakeries to depend highly on imported wheat for bread and other confectionaries. Foreign Agricultural Service (FAS) Lagos under the United States Department of Agriculture forecasts that wheat imports in Marketing Year (MY) 2019/20 is estimated to be 5.6 million metric tons, which is up by almost 4\% compared to MY 2018/19. The rise in wheat consumption is attributable to the population growth of about $2.54 \%$ (2015-20), with Nigerians increasingly consuming greater amounts of wheatflour based products [6]. Successive governments in Nigeria, in a bid to reduce the increasing cost of wheat importation, enacted wheat control policies ranging from a complete ban in the years 1987 to 1991 , via composite flour approach, which included $5 \%$ cassava inclusion from 2007 to $2010,10 \%$ cassava inclusion from 1979 to 2007 and up to $40 \%$ cassava inclusion in 2012 [7]. These policies have not been successful due to the undesired physical quality of wheat-cassava bread.

Though Wheat gluten plays a vital role in the quality and structure of baked bread, a small fraction of the flour matrix can be replaced with other non-wheat flour without affecting its final bread quality.

The use of local and available flours which could produce similar characteristics as gluten or support the available gluten strands during fermentation, proofing and baking would make the applicability of composite flour technology successful.

African Yam Bean (AYB) which is a drought-resistant leguminous crop of tropical African origin is the second biggest and one of the most economically important families among the dicotyledons. Despite its abundant yielding potentials, the crop is still largely underexploited and under-utilized [8]. Its successful inclusion in bread baking application could attach more value and importance to the crop as more attention would be given to it with a resultant increase in annual crop yield. In spite of huge investments made by the Federal Government in the cassava bread initiative over a period of 34 years, the project has remained a pipe dream [9]. According to Eduardo et al. [10] commercial production of wheat-cassava bread is still difficult due to impaired bread structure. Research has been in progress to enhance the specific volume and texture of wheat-cassava bread by adding bread improvers such as hydrocolloids, enzymes, and emulsifiers [11-13]. Shittuet al. [14] has shown that bread with improved specific volume and crumb softness can be made from composite cassava-wheat flour with added xanthan gum. But very little has been done by utilizing this native and underutilized crop of Nigerian origin to improve the quality of wheatcassava bread. Also, utilizing a non-gluten protein may help compensate for some lost protein by substituting more fraction of wheat flour and therefore can help in proper shaping of the bread structure and texture [15]. This paper seeks to exploit the use of AYB flour as an indigenous legume crop to improve the physical and textural properties of Wheat-Cassava composite bread in other to enhance its acceptability.

\section{MATERIALS AND METHODS}

\subsection{Materials}

Creamy variegated African Yam Bean (AYB) seeds (Sphenostylisstenocarpa) and Cassava roots (Manihot esculenta) were purchased at a food market in Kubwa, Federal Capital Territory, Abuja in Nigeria. Commercial grade hard wheat grains were procured from Owode market in Oyo state, Nigeria. Samples of the materials are shown in Plate 1. Other bread baking ingredients were also obtained from Owode market.

The cassava roots were processed into flour using the method described by IITA, [16] as shown in the process flowchart in Figure $1 \mathrm{~b}$. The peeled cassava samples were washed with potable water. The cleaned tubers were later transferred to a grating machine which grated the cassava tubers to mash. The mash was dewatered manually to about $40 \%$ moisture. The cake was pulverized and subjected to drying in an oven, which was set at a temperature of $100^{\circ} \mathrm{C}$ and dried to $8-10 \%$ moisture level. After drying, the cake was milled using hammer mills. The Cassava Flour (CF) obtained from the process was passed through $0.5 \mathrm{~mm}$ sieve mesh for uniform size particles and packed in high-density polyethylene bags for subsequent use. The flour of the three crops was prepared as shown in the process flow charts of Figure 1.

\subsection{Methods}

This study was conducted at the Baking Laboratory of Food Science and Technology of Federal University of Agriculture, Abeokuta, Nigeria. 


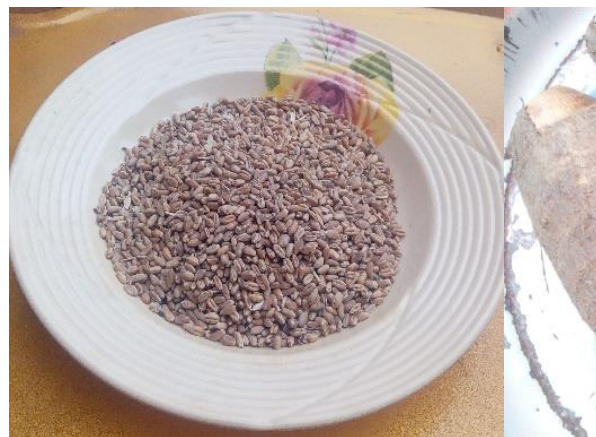

(a)

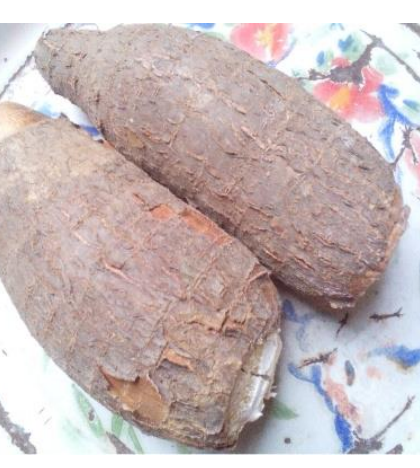

(b)

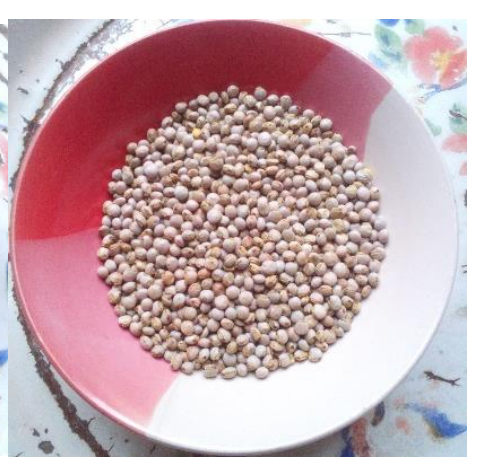

(c)

Plate 1: Some selected samples of (a) Wheat grain (b) Cassava tubers (c) AYB seeds.

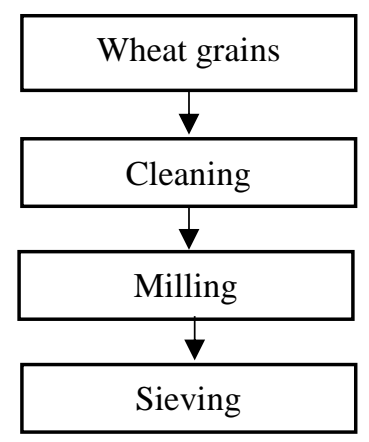

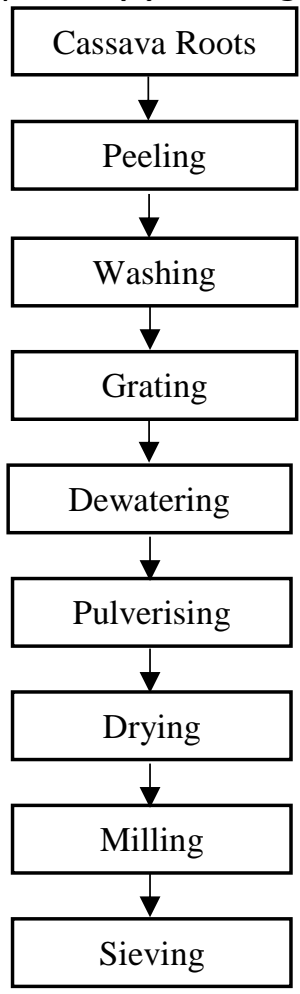

(b)

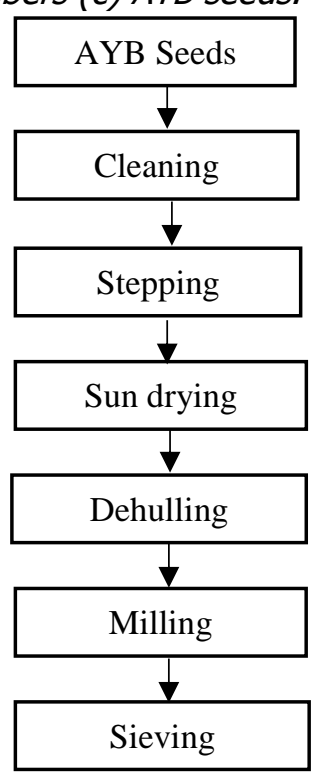

(c)

Figure 1: Process Flow process for the flours production: (a) Wheat[17], (b) Cassava[16], (c) AYB [18].

The process flow chat for the Bread baking was shown in Figure 2. Mixing of flour to attain uniform distribution of flour particle was done for 10 minutes, while kneading was done manually for 7 minutes to develop the gluten structure of the dough when hydrated[19]. Dough proofing was done in a proofing chamber set to $37^{\circ} \mathrm{C}$ for $30 \mathrm{~min}$ at $78-80 \%$ Relative Humidity [20] before baking in a preheated oven at about $220^{\circ} \mathrm{C}$ for 20 minutes [21].

\subsection{Design of Experiment}

D-optimal Mixture design (custom) method of Design Expert (version11, 2011, Stat-Ease Co., USA) was used for the model fitting of the experimental data. The design involved sixteen (16) experimental runs comprising six (6) required model points, five (5) lack of fit points and five (5) replicate points in the design space. Substitution levels of the mix components ranged from $80 \%$ to $100 \%$ for wheat flour, from $0 \%$ to $10 \%$ for cassava flour and from $0 \%$ to $10 \%$ for $A Y B$ flour. Proofing and baking periods were constant for all the experimental samples in the experiments. The design matrix as generated by the software is presented in Table 1. Baker's ingredients percentages by the total mass of flour used in this study is shown in Table 2.

\subsection{Determination of Loaf Specific Volume}

The weights $(\mathrm{g})$ of baked bread samples were taken after sufficiently cooling in desiccators by using a 
digital balance ( $0.01 \mathrm{~g}$ accuracy). The bread loaf volume $\left(\mathrm{cm}^{3}\right)$ was determined using a modified standard seed displacement method [23]. Since rapeseed was not available, millet seeds were used for volume displacement experiment. The container used for measurements was a pan of $14.9 \mathrm{~cm} \times$ $9.3 \mathrm{~cm} \times 7.8 \mathrm{~cm}$. The loaf was placed in the container of known volume $\left(1080.846 \mathrm{~cm}^{3}\right)$ into which millet seeds were poured until the container was filled to the brim and levelled off by a straight-edged baton moving in the direction of the container's length axis. The volume of seed poured into the container subtracted from the volume of the container gives the loaf volume $\left(\mathrm{cm}^{3}\right)$ as shown in equation 1 .

$$
\begin{aligned}
\text { Loaf volume }= & \text { vol. of container } \\
& - \text { vol. of poured grain }
\end{aligned}
$$

The loaf specific volume was calculated by dividing volume $\left(\mathrm{cm}^{3}\right)$ by loaf weight $(\mathrm{g})$ taken $24 \mathrm{hrs}$ after baking as expressed in equation 2 .

Loaf Specific Volume (LSV)

$$
=\frac{\text { Loaf volume }\left(\mathrm{cm}^{3}\right)}{\text { Loaf weight }(\mathrm{g})}
$$

The minimum acceptable specific loaf volume for whole wheat bread as described by Standard Organization of Nigeria (SON) is $2.0 \mathrm{~cm}^{3} / \mathrm{g}$ [24].

\subsection{Bread Crumb Hardness}

The textural analysis was carried out to determine crumb softness/hardness. The textural analysis of the bread crumb was done using a Perten Instrument (TVT-300XPM) by double-cycle compression Texture Profiles Analysis (TPA) method. The bread loaf was sliced into a cube of $25 \mathrm{~mm}$ thickness using a stainless kitchen bread knife. The extreme sides (back) of each loaf were discarded. For the TPA a $25 \mathrm{~mm}$-diameter probe was inserted into the prepared sample cube at $40 \%$ strain, speed of $2 \mathrm{~mm} / \mathrm{s}$ and trigger force of $5 \mathrm{~g}$ [25].The TPA data were used to determine the crumb hardness.

\subsection{Bread Crumb Colour Index}

The crumb colour was measured at the surface of each crumb using the L* Parameter (luminosity) according to colour space CIELab system, with a colourimeter (CR-400, Konica Minolta, chromameter, Tokyo, Japan).

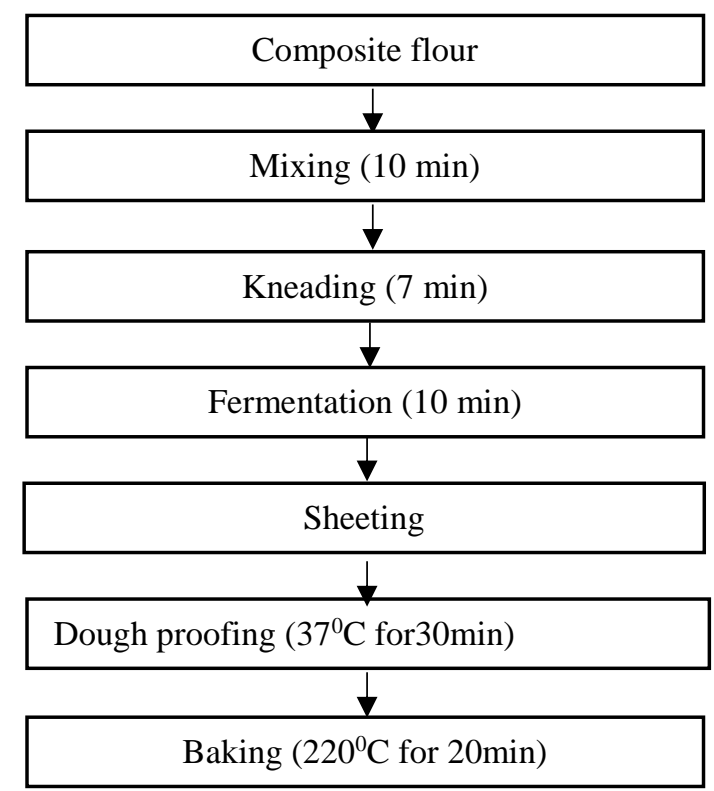

Figure 2: Process Flow chart for bread production [22].

Table 1: Design matrix for the experimental investigation

\begin{tabular}{ccccccc}
\hline Run & $\begin{array}{c}\text { A: } \\
\text { Wheat Flour } \\
\%\end{array}$ & $\begin{array}{c}\text { B: } \\
\text { Cassava Flour } \\
\%\end{array}$ & $\begin{array}{c}\text { C: } \\
\text { AYB } \\
\text { Flour } \\
\%\end{array}$ & $\begin{array}{c}\text { Observed Bread } \\
\text { Crumb Hardness, } \\
\text { N }\end{array}$ & $\begin{array}{c}\text { Observed Loaf } \\
\text { Specific Volume } \\
\mathrm{cm}^{3} / \mathrm{g}\end{array}$ & $\begin{array}{c}\text { Observed } \\
\text { Crumb Colour } \\
\text { Index }\end{array}$ \\
\hline 1 & 100 & 0 & 0 & & \\
2 & 90 & 0 & 10 & & \\
3 & 90 & 4 & 6 & & \\
4 & 80 & 10 & 10 & & \\
5 & 100 & 0 & 0 & & \\
6 & 95 & 3 & 2 & & \\
7 & 93 & 7 & 0 & & \\
8 & 87 & 10 & 3 & & \\
9 & 80 & 10 & 10 & & \\
10 & 90 & 10 & 0 & & \\
11 & 94 & 0 & 6 & & \\
12 & 95 & 0 & 5 & & \\
13 & 90 & 0 & 10 & & \\
14 & 85 & 8 & 8 & & \\
15 & 90 & 10 & 0 & & \\
16 & 95 & 0 & 5 & & \\
\hline
\end{tabular}


Table 2: Proportion of ingredients used for all formulation

\begin{tabular}{lll}
\hline Ingredient & Baker's Percentage & Composition \\
\hline Composite flour & $100 \%$ & $151.6(\mathrm{~g})$ \\
Water & $62 \%$ & $94(\mathrm{ml})$ \\
Yeast & $3 \%$ & $4.5(\mathrm{~g})$ \\
Salt & $2 \%$ & $3.0(\mathrm{~g})$ \\
Sugar & $4 \%$ & $6.1(\mathrm{~g})$ \\
Margarine & $3 \%$ & $4.5(\mathrm{~g})$ \\
\hline
\end{tabular}

(Source: bakerpedia.com)

The L*a*b* colour space provides a precise colour communication between a company and its supply chain to ensure products are made to exact colour specifications. $L^{*}$ indicates lightness while $a^{*}$ and $b^{*}$ are chromaticity coordinates. $a^{*}$ and $b^{*}$ are colour directions: $+a^{*}$ is the red axis, $-a^{\prime}$ is the green axis, $+b^{*}$ is the yellow axis and $-b^{*}$ is the blue axis.

The results for $a^{*}$ and $b^{*}$ were collected in duplicate and the colour index of the mean was calculated as shown in equation 2, [26].

Crumb Colour Index of bread (CCI)

$$
=\sqrt{(a *)^{2}+(b *)^{2}}
$$

\section{RESULTS AND DISCUSSION}

\subsection{Data Analysis and Models Development}

Some of the quality characteristics that determine the choice of bread by consumers include appearances of (size, shape, loaf specific volume) the loaf, bread crumb colour, and the crumb texture, which is roughly checked by pressing the bread with fingers [27].The results of the experiments are shown in Table 3.

\subsubsection{Bread Crumb Hardness}

In this study, Bread Crumb Hardness $(\mathrm{BCH})$ ranged from 18.42 to $44.14 \mathrm{~N}$, with Run five (5) having the least $\mathrm{BCH}$ which was the bread sample made with $100 \%$ wheat flour as more gluten strands are available for rising the dough during fermentation/proofing which will eventually form a light textured and less compact crumb. $\mathrm{BCH}$ was maximum when the mix proportion of wheat flour, cassava flour and AYB flour was $80 \%, 10 \%$ and $10 \%$ respectively which is due to the insufficient gluten strand available for rising, therefore forming a more compact and impaired bread structure.

To predict the effects of the mix ratio on the physical characteristics of the dough and bread, a model was developed for each of the response variables studied. The selected-response variables are Bread Crumb hardness (BCH), Loaf Specific Volume (LSV), and Crumb Colour Index (CCI). The analysis of variance (ANOVA) table for $\mathrm{BCH}$ analysis is presented in Table 4.

Table 3: Results of the experimental investigations

\begin{tabular}{|c|c|c|c|c|c|c|c|c|c|}
\hline$\stackrel{\complement}{\supset}$ & $\begin{array}{c}\text { A: } \\
\text { Wheat } \\
\text { Flour }\end{array}$ & $\begin{array}{c}\text { B: } \\
\text { Cassav } \\
\text { a Flour }\end{array}$ & $\begin{array}{c}\text { C: } \\
\text { AYB } \\
\text { Flour }\end{array}$ & $\begin{array}{c}\text { Observed } \\
\text { Bread } \\
\text { Crumb } \\
\text { Hardness }\end{array}$ & $\begin{array}{c}\text { Predicted } \\
\text { Bread } \\
\text { Crumb } \\
\text { Hardness }\end{array}$ & $\begin{array}{c}\text { Observed } \\
\text { Loaf } \\
\text { Specific } \\
\text { Volume }\end{array}$ & $\begin{array}{c}\text { Predicted } \\
\text { Loaf } \\
\text { Specific } \\
\text { Volume } \\
\end{array}$ & $\begin{array}{c}\text { Observed } \\
\text { Crumb } \\
\text { Colour } \\
\text { Index } \\
\end{array}$ & $\begin{array}{c}\text { Predicted } \\
\text { Crumb } \\
\text { Colour } \\
\text { Index } \\
\end{array}$ \\
\hline & $\%$ & $\%$ & $\%$ & $\mathrm{~N}$ & $\mathrm{~N}$ & $\mathrm{~cm}^{3} / \mathrm{g}$ & $\mathrm{cm}^{3} / \mathrm{g}$ & & \\
\hline 1 & 100 & 0 & 0 & 22.35 & 18.68 & 2.29 & 2.30 & 19.30 & 19.36 \\
\hline 2 & 90 & 0 & 10 & 34.07 & 34.55 & 1.89 & 1.90 & 18.28 & 18.25 \\
\hline 3 & 90 & 4 & 6 & 32.48 & 29.78 & 1.82 & 1.81 & 19.03 & 18.88 \\
\hline 4 & 80 & 10 & 10 & 44.14 & 38.46 & 1.72 & 1.73 & 18.75 & 18.77 \\
\hline 5 & 100 & 0 & 0 & 18.42 & 18.68 & 2.31 & 2.30 & 19.19 & 19.36 \\
\hline 6 & 95 & 3 & 2 & 28.44 & 23.03 & 1.95 & 1.97 & 19.06 & 19.06 \\
\hline 7 & 93 & 7 & 0 & 19.99 & 21.42 & 2.02 & 2.00 & 18.69 & 18.65 \\
\hline 8 & 87 & 10 & 3 & 24.06 & 27.36 & 2.17 & 2.17 & 19.26 & 19.03 \\
\hline 9 & 80 & 10 & 10 & 35.79 & 38.46 & 1.75 & 1.73 & 18.82 & 18.77 \\
\hline 10 & 90 & 10 & 0 & 22.14 & 22.60 & 1.96 & 1.98 & 18.55 & 18.63 \\
\hline 11 & 94 & 0 & 6 & 24.35 & 28.20 & 1.91 & 1.92 & 19.08 & 19.10 \\
\hline 12 & 95 & 0 & 5 & 24.02 & 26.62 & 1.94 & 1.95 & 19.76 & 19.23 \\
\hline 13 & 90 & 0 & 10 & 34.09 & 34.55 & 1.91 & 1.90 & 18.29 & 18.25 \\
\hline 14 & 85 & 8 & 8 & 34.04 & 33.52 & 1.88 & 1.88 & 18.57 & 18.82 \\
\hline 15 & 90 & 10 & 0 & 21.25 & 22.60 & 1.98 & 1.98 & 18.54 & 18.63 \\
\hline 16 & 95 & 0 & 5 & 25.48 & 26.62 & 1.99 & 1.95 & 19.05 & 19.23 \\
\hline
\end{tabular}


Development of Optimized Substitution Ratio for Wheat-Cassava-African Yam Bean Flour Composite..., l. E. Nwatu, et. al.

Table 4: ANOVA table for Bread Crumb Hardness

\begin{tabular}{lrrrrrl}
\hline \multicolumn{1}{c}{ Source } & Sum of Squares & df & Mean Square & F-value & p-value & \\
\hline Model & 642.10 & 2 & 321.05 & 32.60 & $<0.0001$ & significant \\
Linear Mixture & 642.10 & 2 & 321.05 & 32.60 & $<0.0001$ & \\
Residual & 128.04 & 13 & 9.85 & & & \\
Lack of Fit & 83.99 & 8 & 10.50 & 1.19 & 0.4425 & not significant \\
Pure Error & 44.05 & 5 & 8.81 & & & \\
Cor Total & 770.14 & 15 & & & & \\
\hline
\end{tabular}

The final predictive equation in terms of actual component for the bread specific volume is presented in equation 3 .

$\mathrm{BCH}=0.1868 \times \mathrm{W}+0.5783 \times \mathrm{C}+1.7735$

$$
\times \text { AYB }
$$

Where, $\mathrm{BCH}=$ Bread Crumb hardness, $\mathrm{W}=$ Ratio for wheat $(\%), C=$ Ratio for cassava (\%), and $A Y B=$ African Yam Bean Ratio (\%).

The coefficient of determination $\left(R^{2}\right)$ of 0.8337 represents a good fit at $p<0.01$, which indicates the suitability of the model to predict the response with a good degree of accuracy. The model Lack of fit with F-value of 1.19 and $P$-value of 0.4425 supports the goodness of fit of the model. The response surface plot is shown in Figure 3.

The plot of predicted values of the $\mathrm{BCH}$ against observed values helps to check the validity of the model by observing how close the points are scattered around the trend line of the graph. This plot is presented in Figure 4.

From Figure 4, the points lie very close to the trend line showing reasonable agreement between the predicted and observed data. This shows that the prediction of $\mathrm{BCH}$ by the model was good.

The optimal solution was located at the mixture ratio of $100 \%$ Wheat flour, $0 \%$ cassava flour and $0 \%$ AYB flour for Bread Crumb Hardness of $18.42 \mathrm{~N}$.

\subsubsection{Loaf Specific Volume (LSV):}

The specific volume of a loaf is a good indicator of bread quality. It represents the ability of gluten strands to retain enough gas released during fermentation and dough proofing. Higher gas retention ability will lead to a higher specific volume $[28,29]$. It has been reported in the literature as a definite measure of loaf size $[14,30]$. It is also used by the Standard Organization of Nigeria (SON) as a measure of standard bread quality [24]. It is the ratio of loaf volume $\left(\mathrm{cm}^{3}\right)$ to loaf weight $(\mathrm{g})$.

In this study, loaf specific volume ranged from 1.72 to $2.31 \mathrm{~cm}^{3} / \mathrm{g}$, with Run five (5) having the maximum LSV which is expected as bread was made with
$100 \%$ wheat flour due to its abundant vital gluten content. LSV was minimum when the mix proportion of wheat flour, cassava flour and AYB flour was $80 \%$, $10 \%$ and $10 \%$ respectively. A loaf specific volume for whole-wheat bread should not be less than $2.0 \mathrm{~cm}^{3} / \mathrm{g}$ [24].

Ngozi [31] reported specific volume which ranged from 2.16 to $3.51 \mathrm{~cm}^{3} / \mathrm{g}$ for bread made by substituting parts of wheat flour with whole-wheat flour. Malomo et al., [32] reported a specific volume of bread that ranged from 2.08 to $3.39 \mathrm{~cm}^{3} / \mathrm{g}$ with $5 \%$ breadnut flour substitution level and $100 \%$ wheat bread significantly different from others. The result of the ANOVA for LSV is presented in Table 5.

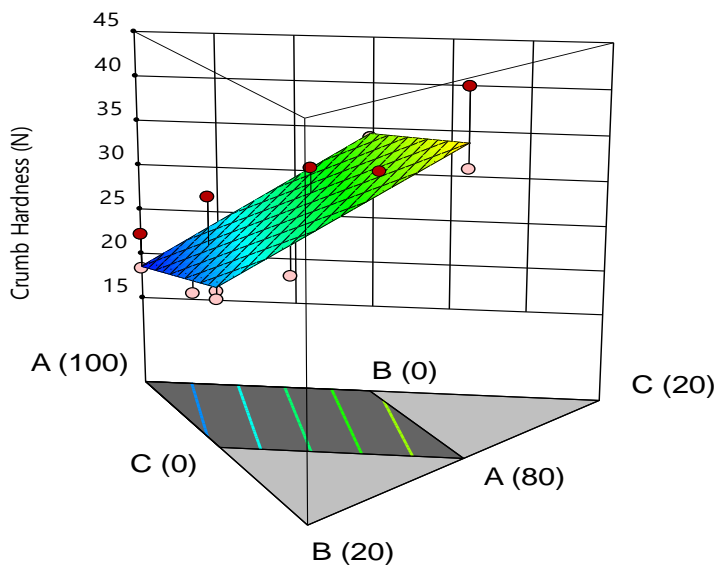

Fig. 3: Response surface plot for Bread Crumb Hardness.

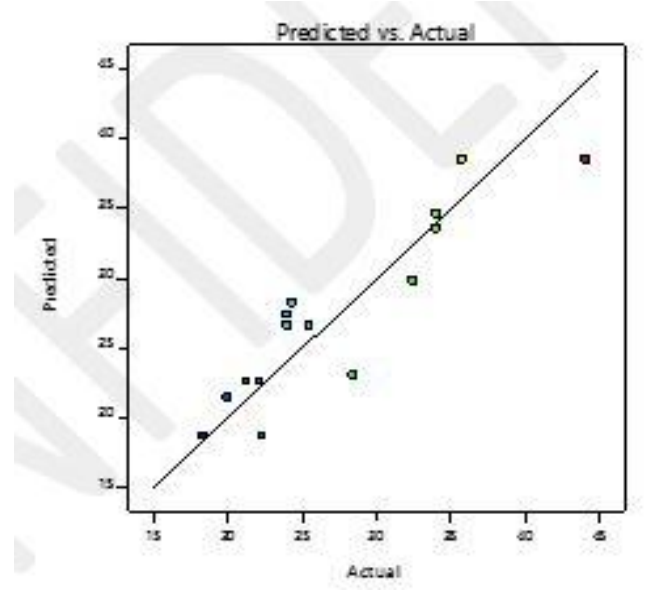

Fig. 4: Graph of predicted against observed data for $\mathrm{BCH}$

Vol. 39, No. 4, October 2020 
Development of Optimized Substitution Ratio for Wheat-Cassava-African Yam Bean Flour Composite..., l. E. Nwatu, et. al.

Table 5: ANOVA table for LSV

\begin{tabular}{lrrrrrl}
\hline \multicolumn{1}{c}{ Source } & Sum of Squares & df & Mean Square & F-value & p-value & \\
\hline Model & 0.4136 & 7 & 0.0591 & 122.23 & $<0.0001$ & significant \\
Linear Mixture & 0.2763 & 2 & 0.1382 & 285.82 & $<0.0001$ & \\
AB & 0.0149 & 1 & 0.0149 & 30.92 & 0.0005 & \\
AC & 0.0395 & 1 & 0.0395 & 81.64 & $<0.0001$ & \\
BC & 0.0017 & 1 & 0.0017 & 3.56 & 0.0958 & \\
AB(A-B) & 0.0274 & 1 & 0.0274 & 56.76 & $<0.0001$ & \\
BC(B-C) & 0.0610 & 1 & 0.0610 & 126.10 & $<0.0001$ & \\
Residual & 0.0039 & 8 & 0.0005 & & & \\
Lack of Fit & 0.0016 & 3 & 0.0005 & 1.14 & 0.4191 & not significant \\
Pure Error & 0.0023 & 5 & 0.0005 & & & \\
Cor Total & 0.4174 & 15 & & & & \\
\hline
\end{tabular}

P-value less than 0.05 indicates that model terms are significant. In this case, $A, B, C, A B, A C, A B(A-B)$ and $B C(B-C)$ are significant model terms. The Lack of Fit F-value of 1.14 implies the Lack of Fit is not significant relative to the pure error. There is a $41.91 \%$ chance that a Lack of Fit F-value this large could occur due to noise. Non-significant lack of fit is good since we want the model to fit.

The predictive equation of LSV in terms of the mixture ratios of the three flours is given in equation 4.

$$
\begin{aligned}
\mathrm{LSV}=0.0230 \times & \mathrm{W}-5.8880 \times \mathrm{C}+0.5105 \times \mathrm{AYB} \\
& +0.0949 \times \mathrm{W} \times \mathrm{C}-0.0059 \times \mathrm{W} \\
& \times \mathrm{AYB}+0.0314 \times \mathrm{C} \times \mathrm{AYB} \\
& -0.0004 \times \mathrm{W} \times \mathrm{C} \times(\mathrm{W}-\mathrm{C}) \\
& +0.0015 \times \mathrm{C} \times \mathrm{AYB} \times(\mathrm{C} \\
& -\mathrm{AYB})
\end{aligned}
$$

The coefficient of determination $\left(R^{2}\right)$ is 0.9907 and F-value is $122.23(p<0.0001)$ at $95 \%$ confidence interval which is an indication of a good fit. The implication is that there is only a $0.01 \%$ chance that an F-value this large could occur due to noise. The coefficients of the equation 4 show that LSV was significantly affected by the interaction of the three flour components.

The optimal solution was located at the mixture ratio of $87 \%$ Wheat flour, $10 \%$ cassava flour and $3 \%$ AYB flour for LSV of $2.17 \mathrm{~cm}^{3} / \mathrm{g}$. The response surface plot for LSV is shown in Figure 5.

The validation plot of predicted against observed values of LSV is presented in Figure 6. The points lie very close to the trend line showing reasonable agreement between the predicted and observed data. This shows that the prediction of LSV was very good.
This trend as has been explained earlier shows a very good prediction given that the entire points lie very close to the trend line.

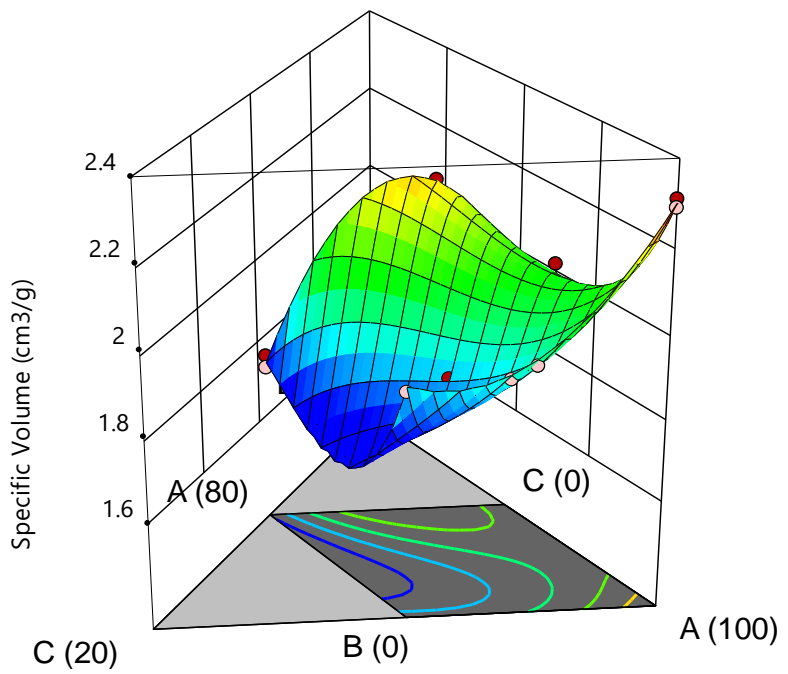

Fig. 5: Surface plot of LSV against mixture ratios

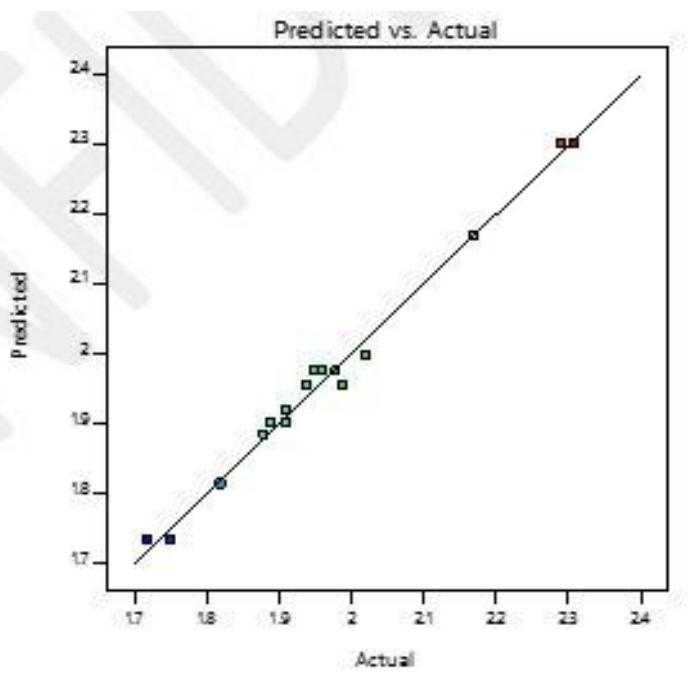

Fig. 6: Graph of predicted against observed data for LSV 


\subsubsection{Crumb Colour Index (CCI):}

Sugar and the by-products of proteins present in the dough result in enzymatic and Millard reactions during the baking process and give the loaf brownish appearance [33]. Also, the physiochemical property of milled flour is another important factor in the bread crumb colour index. Other important sources of the colour of the bread crumb are the wheat bran and germ present in the flour, which give it a brown-like appearance [34].The colour index was estimated from a* and $b^{*}$ using equation (2). Sample Run 8 gave the following value for $a^{*}$ and $b^{*}$ as 4.54 and 18.72 respectively which gives a crumb colour index of 19.26.

In this study, CCI ranged from 18.28 to 19.76 , with Run 2 having the minimum CCI which is made with $90 \%$ wheat flour and $10 \%$ AYB flour due to its brighter appearance than $100 \%$ Wheat flour product. Also, CCI was maximum when the mix proportion was $100 \%$ wheat flour, due to the high presence of wheat bran and germ.

The result of the ANOVA for CCI is presented in Table 6.

Model terms A, B, C, AB, AC and BC are all significant. The Lack of Fit F-value of 3.92 implies the Lack of Fit is not significant relative to the pure error. There is an $8.01 \%$ chance that a Lack of Fit F-value this large could occur due to noise. Nonsignificant lack of fit is good since we want the model to fit.

The predictive equation of CCI in terms of the mixture ratios (\%) of the three flours is given in equation 5.

$$
\begin{aligned}
\mathrm{CCI}=0.1936 \times \mathrm{W} & +1.0040 \times \mathrm{C}-1.4500 \times \mathrm{AYB} \\
& -0.0098 \times \mathrm{W} \times \mathrm{C}+0.0170 \times \mathrm{W} \\
& \times \mathrm{AYB}+0.0197 \times \mathrm{C} \times \mathrm{AYB}(5)
\end{aligned}
$$

The coefficient of determination $\left(R^{2}\right)$ is 0.8954 and F-value is $17.11 \quad(p=0.0001)$ at $95 \%$ confidence interval which is an indication of a good fit. The implication is that there is only a $0.01 \%$ chance that an F-value this large could occur due to noise. The coefficients of the equation 5 show that CCI was significantly affected by the interaction of the three flour components. The optimal solution was located at the mixture ratio of $95 \%$ Wheat flour, 3\% cassava flour and $2 \%$ AYB flour for CCI of 19.06. The response surface plot for CCI is shown in Figure 7. The validation plot of predicted against observed values of $\mathrm{CCI}$ is presented in Figure 8 .

Table 6: ANOVA table for CCI

\begin{tabular}{lrrrrrl}
\hline \multicolumn{1}{c}{ Source } & Sum of Squares & \multicolumn{1}{c}{ df } & Mean Square & F-value & p-value & \\
\hline Model & 1.83 & 5 & 0.3654 & 17.11 & 0.0001 & significant \\
Linear Mixture & 0.5516 & 2 & 0.2758 & 12.92 & 0.0017 & \\
AB & 0.1146 & 1 & 0.1146 & 5.37 & 0.0430 & \\
AC & 0.4788 & 1 & 0.4788 & 22.42 & 0.0008 & \\
BC & 0.3364 & 1 & 0.3364 & 15.76 & 0.0026 & \\
Residual & 0.2135 & 10 & 0.0214 & & & \\
Lack of Fit & 0.1701 & 5 & 0.0340 & 3.92 & 0.0801 & not significant \\
Pure Error & 0.0434 & 5 & 0.0087 & & & \\
Cor Total & 2.04 & 15 & & & & \\
\hline
\end{tabular}

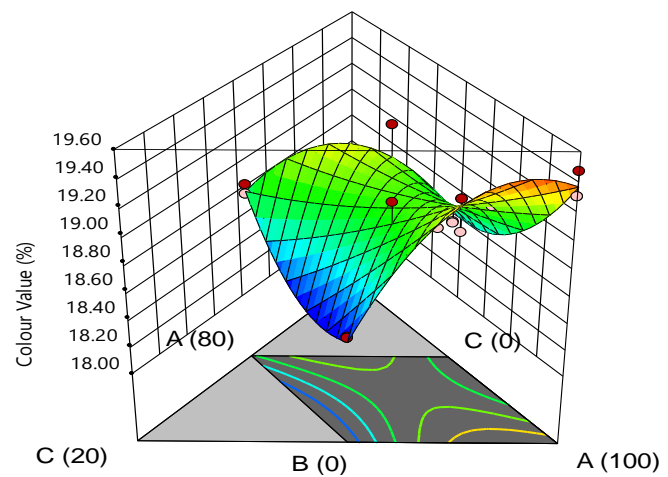

Fig. 7: Surface plot of CCI against mixture ratios

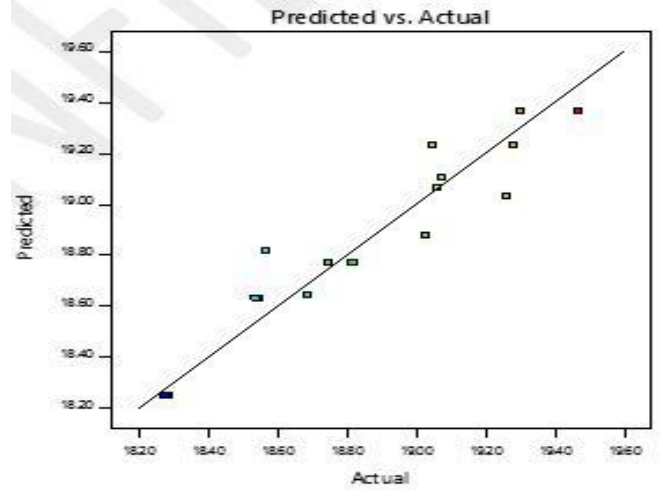

Fig. 8: Graph of predicted against observed data for CCI 
This shows a good prediction given that the entire points lie close to the trend line.

\section{CONCLUSION}

The optimised composite flour of Wheat, Cassava and AYB were developed for improved loaf specific volume, bread crumb hardness as well as the crumb colour index. The objective functions were to obtain the most suitable substitution ratio that will maximize Loaf Specific Volume, minimize Bread Crumb Hardness and Crumb Colour Index. Based on the composite desirability index of 0.61 , the predicted optimal composite mix formulation for enhanced quality of composite bread were $88 \%$, $10 \%$, and $2 \%$ for wheat flour, cassava flour and AYB flour respectively. At this formulation, the predicted loaf specific volume was $2.11 \mathrm{~cm}^{3} / \mathrm{g}$, bread crumb hardness was $25.12 \mathrm{~N}$, and crumb colour index was 18.88.

Variations in mix formulation highly influenced the $\mathrm{BCH}$, LSV and CCI. The predicted optimal loaf specific volume complies with SON standard on the quality specifications given on the loaf specific volume of whole-wheat bread as $2.0 \mathrm{~cm}^{3} / \mathrm{g}$ minimum. Increasing the substitution level of combined AYB flour and Cassava flour up to $10 \%$ impacted the quality of the composite bread produced by reducing loaf specific volume and increasing crumb hardness. This agrees with Yaver and Bilgiçli [35] that CerealLegume Flour Blend (CLFB) in bread formulations lowered the volume in Commercial Bread (CB) and increased the hardness of bread.

This result of study, therefore, confirms that the quality of Wheat-Cassava bread can be enhanced by using AYB flour up to $2 \%$ by systematic substitution and is recommended for adoption by bread industries.

\section{REFERENCES}

[1.] KPMG. "Wheat-based Consumer Foods in Nigeria",KPMG Nigeria, August, 2016. Retrieved from

https://assets.kpmg/content/dam/kpmg/co/pdf/ 005-wheat-based-consumer-foods-in-nigeria.pdf

[2.] Eleazu, C., Eleazu, K., Aniedu, C., Amajor, J., Ikpeama, A., and Ebenzer, I. "Effect of partial replacement of wheat flour with high quality cassava flour on the chemical composition, antioxidant activity, sensory quality, and microbial quality of bread", Preventive nutrition and food science, 19(2), (2014), 115.
[3.] Abdelghafor, R. F., Mustafa, A. I., Ibrahim, A. M. H., and Krishnan, P. G. "Quality of bread from composite flour of sorghum and hard white winter wheat", Advance Journal of Food Science and Technology, 3(1), (2011), 9-15.

[4.] Kyrø, C., and Tjønneland, A."Whole grains and public health", Danish Cancer Society Research Center, Strandboulevarden 49,(2016), 2100 Copenhagen, Denmark.

[5.] Dalton, S. M. C., Tapsell, L. C., and Probst, Y. "Potential health benefits of whole grain wheat components", Nutrition Today, 474), (2012), 163-174.

[6.] USDA FAS Grain Report. "Nigeria's Imports of Wheat and Rice to Rise. Grain and Feed Annual 2019', Retrieved from https://apps.fas.usda.gov/newgainapi/api/repor $\mathrm{t} /$ downloadreportbyfilename?filename $=$ Grain $\% 2$ 0and\%20Feed\%20Annual Lagos Nigeria 5-62019.pdf.

[7.] Ohimain, E. I. "Overcoming the challenges of implementing the $40 \%$ cassava bread policy in Nigeria", Journal of Scientific Research and Reports, (2015), 305-312.

[8.] IITA. "Cassava in the tropical Africa. A reference manual", International Institute of Tropical Agriculture. Wisbech, Baldings and Mansell International (2010).

[9.] Punch. "Cassava bread, still a mirage after 34 years", Punch Newspaper2016, December 19th, Retrieved from https://punchng.com/cassavabread-still-mirage-34-years/

[10.] Eduardo, M., Svanberg, U., Oliveira, J., and Ahrné, L. "Effect of cassava flour characteristics on properties of cassava-wheat-maize composite bread types", International Journal of Food Science, (2013).

[11.] Shittu, T. A., Aminu, R. A., and Abulude, E. O. "Functional effects of xanthan gum on composite cassava-wheat dough and bread", Food Hydrocolloids, 23(8), (2009), 2254-2260.

[12.] Serventi, L., Skibsted, L. H., and Kidmose, U. "Sensory and textural characterization of composite wheat-cassava bread as a function of lipase dose and storage time", European Food Research and Technology, 246(1), (2020), 2332.

[13.] Eduardo, M., Svanberg, U., and Ahrné, L. "Effect of hydrocolloids and emulsifiers on baking quality of composite cassava-maize-wheat breads", International journal of food science, (2014).

[14.]Shittu, T. A., Raji, A. O., and Sanni, L. O. "Bread from composite cassava-wheat flour: I. Effect of baking time and temperature on some physical 
properties of bread loaf". Food Research International, 4O(2), (2007), 280-290.

[15.]Ziobro, R., Juszczak, L., Witczak, M., and Korus, J. "Non-gluten proteins as structure forming agents in gluten free bread", Journal of food science and technology, 53(1), (2016) 571-580.

[16.] IITA."Cassava Recipes for Household Food Security". Printed in Nigeria by International Institute of Tropical Agriculture (IITA),(2006), Pp: 10-25.

[17.] Papageorgiou, M., and Skendi, A. "Introduction to cereal processing and by-products". In Sustainable Recovery and Reutilization of Cereal Processing By-Products (2018), pp. 1-25. Woodhead Publishing.

[18.] Olapade, A. A., and Oluwole, O. B. "Bread making potential of composite flour of wheatacha (Digitariaexilis staph) enriched with cowpea (Vignaunguiculata L. walp) flour", Nigerian Food Journal, 31(1), (2013), 6-12.

[19.] Bakerpedia. "Kneading", BAKER Academy. Retrieved from https://bakerpedia.com/processes/kneading/ on Febuary 16, 2020.

[20.] Bakerpedia. "Proofer Design", BAKER Academy. Retrieved from https://bakerpedia.com/processes/prooferdesign/ on February 16, 2020.

[21.]Bakerpedia. "Bread Processing", BAKER Academy. $\quad$ Retrieved from https://bakerpedia.com/processes/breadprocessing/on February 16, 2020.

[22.] Nwanya, S. C., Okonkwo, C. B., andNwaoha, I. E. "Effect of Blend Ratio on Thermo-Physical and Sensory Characteristics of Composite Wheat, Cassava and Soy Bread", Nigerian Journal of Technology, 33(2), (2014), 184-191.

[23.] AACC. "Approved methods of American Association of Cereal Chemists". 10 $0^{\text {th }}$ Edn, $A A C C$ International, St. Paul, MN (2000).

[24.] NIS 470. "Nigerian Industrial Standard. Standard of Whole wheat bread". Standard Organisation of Nigeria (SON). ICS 67.060 (2004).

[25.]Dvoráková, P., Buresová, I., and Krácmar, S. "Buckwheat as a gluten-free cereal in combination with maize flour", The Journal of Microbiology, Biotechnology and Food Sciences, 1, 897 (2012).
[26.]Taghinezhad, E., RasooliSharabiani, V., and Kaveh, M. "Modelling and Optimization of Hybrid HIR Drying Variables for Processing of Parboiled Paddy Using Response Surface Methodology", Iranian Journal of Chemistry and Chemical Engineering (IJCCE)(2018).

[27.] Hadnađev, T. R. D., Dokić, L. P., Hadnađev, M. S., Pojić, M. M., Rakita, S. M., and Torbica, A. M. "Changes in quality parameters of bread supplemented with OSA starch during storage". Food and Feed research, 40(2), (2013), 101-108.

[28.] Nada, F. A., and Hasan, S. K. "Preparation and evaluation of gluten free pan bread and noodles". Sciences, 5(04), (2015), 1273-1286.

[29.] Franco, V. A., Garcia, L. G. C., and Silva, F. A. D. "Addition of hydrocolidics in gluten-free bread and replacement of rice flour for sweet potato flour", Food Science and Technology, (AHEAD) (2020).

[30.] Purna, S. K. G., Miller, R. A., Seib, P. A., Graybosch, R. A., and Shi, Y. C. "Volume, texture, and molecular mechanism behind the collapse of bread made with different levels of hard waxy wheat flours", Journal of Cereal Science, 54(1), (2011) 37-43.

[31.] Ngozi, A. A. "Effect of whole wheat flour on the quality of wheat-baked bread", Global Journal of Food Science and Technology, 2(3), (2014) 127133.

[32.] Malomo, S. A., Eleyinmi, A. F., and Fashakin, J. B."Chemical composition, rheological properties and bread making potentials of composite flours from breadfruit, breadnut and wheat", African Journal of Food Science, 5(7), (2011) 400-410.

[33.] Tamanna, N., and Mahmood, N. "Food processing and maillard reaction products: effect on human health and nutrition", International Journal of Food Science, (2015).

[34.]Zhang, J., Hou, H., Dong, H., and Dai, Y. "Effects of bran, shorts and feed flour by ultra-fine grinding on rheological characteristics of dough and bread qualities", African Journal of Biotechnology, 11(15), (2012), 3631-3639.

[35.] Yaver, E., and Bilgiçli, N. "Utilisation of cereallegume flour blends in commercial and traditional bread", Quality Assurance and Safety of Crops and Foods, 10 (3), (2018), 297-306. 